\section{The effects of adrenalectomy}

\section{on protein-carbohydrate choice*}

\author{
ALAN I. LESHNER
}

Bucknell University, Lewisburg, Pa. 17837

The self-selection of dietary protein and carbohydrate was studied in adrenalectomized and intact rats. Adrenalectomized rats decreased protein intake but did not alter carbohydrate intake relative to controls. These data suggest that the reduction in food intake which follows adrenalectomy may reflect an attempt at reducing net protein intake. Further, these data support the position that dietary self-selection patterns reflect the nutritional requirements of the organism.

Dietary self-selection patterns appear to reflect the nutritional requirements of the organism (Mitchell \& Mendell, 1921; Richter, Holt, \& Barelare, 1938; Collier, Leshner, \& Squibb, 1969a; Leshner, Collier, \& Squibb, 1971; Leshner, Siegel, \& Collier, 1972). One technique which has commonly been used in studying this relationship is to manipulate the nutritional requirements of the organism through manipulating hormonal functions.

Manipulating adrenal function, however, has yielded conflicting results. Although it is well documented that adrenlectomy leads to an increase in salt intake, reports of the effects of adrenalectomy on protein and carbohydrate intakes have been contradictory from study to study. Richter (1941a, b) and Soulairac (1967) reported that adrenalectomy leads to a decrease in carbohydrate intake and does not affect protein intake. Clark \& Clauson (1943) found no effect of adrenalectomy on protein or carbohydrate intake. Lát (1967) reported that adrenalectomy decreases protein intake but does not affect carbohydrate intake.

In all of these studies of adrenalectomy and dietary self-selection, the animals were offered a choice of a wide range of dietary components. Since the discrepancy in the findings involves primarily protein and carbohydrate intakes, it was decided to use a protein-carbohydrate choice situation in this study of dietary self-selection by adrenalectomized rats. In this protein-carbohydrate choice situation (Collier, Leshner, \& Squibb, 1969a, b; Leshner, Collier, \& Squibb, 1971), the experimental animals are offered a simultaneous choice of separate protein and carbohydrate fractions,

*This research was supported by Research Grant GB-23912 from the National Science Foundation. The author thanks Vicki Litwin and Kirk Speicher for thanks Vicki Litwin and Kirk Speicher
their assistance with the data collection. both of which contain optimal amounts of fats, minerals, and vitamins.

\section{ANIMALS AND APPARATUS}

The Ss were 32 male hooded rats of the Long-Evans strain. They were approximately 45 days of age at the time of surgery. The animals were housed in standard Wahmann home cages which were fitted with two Wahmann food dishes and two Wahmann calibrated water bottles. The experimental room was maintained on a 12-h light/dark cycle, and the room temperature was controlled at $22^{\circ} \pm 1^{\circ} \mathrm{C}$. The animals were fed either a control diet $(22 \%$ protein) or a choice of a protein fraction $(45 \%$ protein) and a carbohydrate fraction (0\% protein) simultaneously (Collier, Leshner, \& Squibb, 1969a, b; Leshner, Collier, \& Squibb, 1971). All diets were isocaloric at $3.60 \mathrm{cal} / \mathrm{g}$ and contained the optimal levels of fats, minerals, and vitamins.

\section{PROCEDURE}

The animals were assigned, preoperatively, on the basis of body weight to four groups. The four groups were formed according to a two-way factorial design. There were two diet conditions-selection and nonselection-and two surgical conditions-adrenalectomized (adx) and sham adrenalectomized (sham). An adrenalectomy was considered complete if the animal's subsequent intake of a $2 \% \mathrm{NACl}$ (USP) solution was equal to or greater than its intake of water (Moyer \& Been, 1964). Animals in the selection condition were given a simultaneous choice of the protein fraction and the carbohydrate fraction, while those in the nonselection condition were presented with the control diet in both food dishes. Following the operation, all animals were given a 2-week recovery period prior to the start of the experimental period.

During the recovery period, all animals were given ad lib access to the control diet, water and a $2 \% \mathrm{NaCl}$ (USP) solution. During the experimental period, animals in the selection condition were presented with the protein fraction and the carbohydrate fraction simultaneously. During this period, daily recordings were taken of body weight, water intake, salt intake, and food intake from each food dish. On the 36 th day of the experimental period, all animals were sacrificed and the carcasses were examined under a magnifier for remaining adrenal tissue.

Analyses of variance were applied over the daily measures as a function of dietary condition, surgical condition, and days. All results reported as significant differed at the $5 \%$ level or less.

\section{RESULTS AND DISCUSSION}

The results of this experiment are presented in Tables 1 and 2 .

Both selecting and nonselecting animals grew at the same rates $(\mathrm{df}=1 / 28, \quad \mathrm{~F}=1.33$ ). This finding supports the findings of other studies which show that animals given the opportunity to select their diets from protein and carbohydrate fractions select proportions which result in normal growth (Collier, Leshner, \& Squibb, 1969a, b; Leshner, Collier, \& Squibb, 1971; Leshner, Siegel, \& Collier, 1972).

Bilateral adrenalectomy led to a significant $(\mathrm{d} f=1 / 28, \quad F=22.83)$ reduction in water intake, a significant (df $=1 / 28, F=62.65)$ increase in salt intake, and a significant ( $\mathrm{df}=1 / 28$, $F=14.19$ ) increase in total fluid intake as compared with controls. These findings are consistent with the fact that adrenalectomized animals suffer an inability to retain sodium (cf. Moyer \& Been, 1964; Turner \& Bagnara, 1971). Further, maintenance on the selection regimen led to a decrease $(\mathrm{df}=1 / 28, \mathrm{~F}=8.26$ ) in total fluid intake. This reduction in total fluid intake was due to a significant reduction in salt intake by sham, selecting animals relative to controls.

Adrenalectomy led to a reduction

Table 1 Means of Daily Measures

\begin{tabular}{lcccc} 
Group & $\begin{array}{c}\text { Body } \\
\text { Weight (g) }\end{array}$ & $\begin{array}{c}\text { Water } \\
\text { Intake (ml) }\end{array}$ & $\begin{array}{c}\text { Salt } \\
\text { Intake (ml) }\end{array}$ & $\begin{array}{c}\text { Total Fluid } \\
\text { Intake (m) }\end{array}$ \\
\hline Selecting-Adx & 271 & 11.7 & 28.6 & 40.3 \\
Selecting-Sham & 309 & 23.9 & 5.0 & 28.9 \\
Nonselecting-Adx & 274 & 18.4 & $\mathbf{3 0 . 0}$ & 48.4 \\
Nonselecting-Sham & 327 & 24.9 & 12.9 & 37.8 \\
\hline
\end{tabular}


Table 2

Means of Daily Measures

\begin{tabular}{lccccc}
\multicolumn{1}{c}{ Group } & $\begin{array}{c}\text { Protein } \\
\text { Intake } \\
\text { (g) }\end{array}$ & $\begin{array}{c}\text { Carbohy- } \\
\text { Intake } \\
\text { Ig) }\end{array}$ & $\begin{array}{c}\text { Total } \\
\text { Food } \\
\text { Intake } \\
(\mathrm{g})\end{array}$ & $\begin{array}{c}\text { Percent } \\
\text { Protein } \\
\text { Selected }\end{array}$ & $\begin{array}{c}\text { Food } \\
\text { Intake/ } \\
\text { Body } \\
\text { Weight }\end{array}$ \\
\hline Selecting-Adx & 5.9 & 15.9 & $\mathbf{2 1 . 8}$ & 12.2 & $\mathbf{0 . 0 8 1}$ \\
Selecting-Sham & $\mathbf{8 . 0}$ & 14.4 & $\mathbf{2 2 . 4}$ & $\mathbf{1 6 . 1}$ & $\mathbf{0 . 0 7 6}$ \\
Nonselecting-Adx & - & - & $\mathbf{2 0 . 6}$ & - & 0.075 \\
Nonselecting-Sham & - & - & $\mathbf{2 3 . 1}$ & - & $\mathbf{0 . 0 7 0}$ \\
\hline
\end{tabular}

( $d f=1 / 28, \quad F=4.57$ ) in total food intake and to a consequent reduction ( $\mathrm{df}=1 / 28, \mathrm{~F}=25.47$ ) in body weight (cf. Leshner, 1971). In the case of selecting animals, this reduction in food intake was accomplished by a selective reduction $(\mathrm{df}=14, \mathrm{t}=4.12$ ) in protein consumption, since carbohydrate intake was unaffected ( $\mathrm{df}=14, \mathrm{t}=1.63$ ) by adrenalectomy. This finding suggests that the reduction in food intake which follows adrenalectomy (Leshner, 1971) may represent an attempt at reducing net protein intake. The finding that adx reduces protein intake and does not affect carbohydrate intake supports the findings of Lat's studies (1967) but is opposite to the findings of the studies by Richter $(1941 \mathrm{a}, \mathrm{b})$ and Soulairac (1967). Since Levin, Newey, $\&$ Smith (1965) have shown that providing adx rats with supplementary salt counteracts the impairment in the intestinal absorption of carbohydrates which follows adrenalectomy, it seems reasonable that the adx rats in the present study did not alter their carbohydrate intakes. This interpretation cannot, however, explain the fact that in Richter's studies, adx rats reduced carbohydrate intakes in spite of being given the opportunity to consume a $3 \% \mathrm{NaCl}$ solution. The decreased protein consumption of adrenalectomized rats in the present study may reflect an inability of these animals to completely utilize dietary protein in the absence. of the gluconeogenic actions of the glucocorticoids (Turner \& Bagnara, 1971).

Thus, the results of this experiment support the position that adrenalectomized rats decrease protein intakes and do not alter carbohydrate intakes, at least when they are given the opportunity to ingest supplementary salt. Further, the findings of this experiment lend additional support to the position that rats given the opportunity to select the components of their diets do so in accordance with their nutritional requirements.

\section{REFERENCES}

CLARK, W. G., \& CLAUSEN, D. F. Dietary "self-selection" and appetites of untreated and treated adrenalectomized rats. American Journal of Physiology, $1943,139,70-79$.

COLLIER, G., LESHNER, A. I., \& SQUIBB, R. L. Dietary self-selection in active and nonactive rats. Physiology \& Behavior, 1969a, 4, 79-82.
COLLIER, G.. LESHNER, A. I.. \& SQUIBB, R. E. Self-selection of natural and purified dietary protein. Physiology \& Behavior, 1969b, 4, 83-86.

LÁT, J. Self-selection of dietary components. In Handbook of physiology, Sec. 6: Alimentary canal. Washington. D.C: American Physiological Society, 1967.

LESHNER, A. I. The adrenals and the regulatory nature of running wheel activity. Physiology \& Behavior, 1971,6. $551-558$.

LESHNER, A. I., COLLIER, G. H., \& SQUIBB, R. L. Dietary self-selection at cold temperatures. Physiology \& Behavior, 1971, 6, 1-3.

LESHNER, A. I., SIEGEL, H. I., \& COLLIER, G. H. Dietary self-selection by pregnant and lactating rats. Physiology \& Behavior, $1972,8,151 \cdot 154$.

LEVIN, R. J., NEWEY, H., \& SMITH, D. H The effects of adrenalectomy and fasting on intestinal function in the rat. Journal of Physiology, 1965, 177, 58-73.

MITCHELL, H. S.. \& MENDEL, L. B Studies in nutrition: The choice between adequate and inadequate diet as made by rats and mice. American Journal of Physiology, 1921, 58, 211-225.

MOYER, K. E., \& BEEN, R. T. Effect of adrenalectomy on food, water and saltwater consumption in the rat: A methodological study. Journal of Genetic Psychology, 1964, 104, 297-300.

RICHTER, C. P. Sodium chloride and dextrose appetite of untreated and treated adrenalectomized rats. Endocrinology, 1941a, 29, 115-125.

RICHTER, C. P. Decreased carbohydrate appetite of adrenalectomized rats. Proceedings of the Society for Experimental Biology \& Medicine, $1941 \mathrm{~b}, 48,577-579$.

RICHTER, C. P., HOLT, L. E., \& BARELARE, B. Nutritional requirements for normal growth and reproduction in rats studied by the self selection method. American Journal of Physiology, 1938 $122,734-744$

SOULAIRAC, A Control of carbohydrate intake. In Handbook of physiology. Sec. 6: Alimentary canal. Washington. D.C: American Physiological Society, 1967.

TURNER, C. D. \& BAGNARA, J. T General endocrinology. (5th ed.) Philadelphia: Saunders, 1971. 